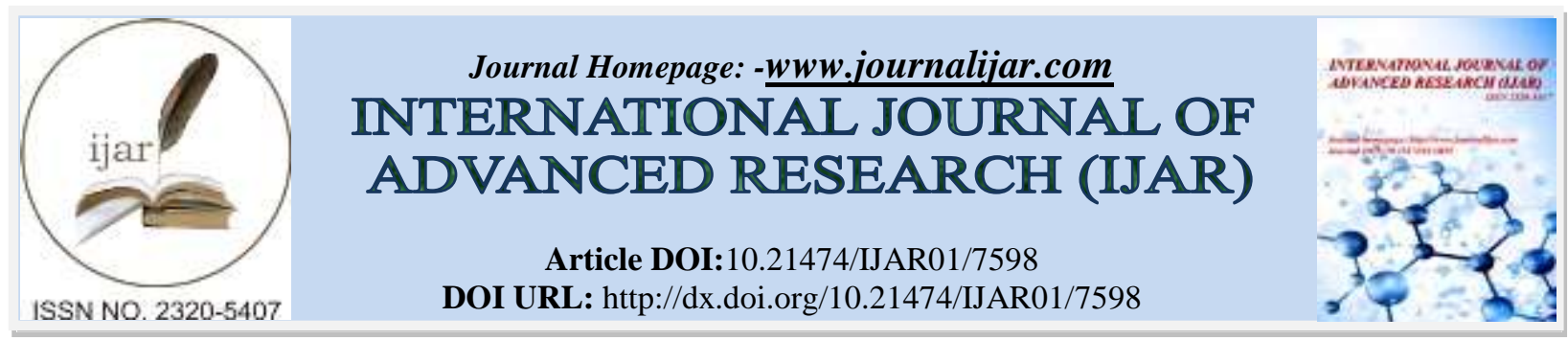

RESEARCH ARTICLE

\title{
IDENTIFICATION OF BIOACTIVE COMPOUNDS AND ANTIBACTERIAL ACTIVITY OF MARINE GASTROPOD CONUS ACHATINUS GMELIN, 1791
}

V.Chandramathi ${ }^{1}$ and R.D. Thilaga ${ }^{2}$.

1. P.G \& Research Department of Zoology, V.O. Chidambaram College, Thoothukudi- 628008.

2. P.G.\& Research Department of Zoology, St. Mary's College (Autonomous).

\section{Manuscript Info}

Manuscript History

Received: 20 June 2018

Final Accepted: 22 July 2018

Published: August 2018

Keywords:-

Mollusc, Conus achatinus, antibacterial, bioactive compounds

\section{Abstract}

ThThe aim of the present study is to screen a molluscan gastropod, Conus achatinus to find out the possible bioactive compounds present in the whole body tissues of experimental animal. The antibacterial activity was assayed against ten bacterial pathogens by Disc Diffusion Technique at three different concentrations. The crude methanolic extract showed significant antibacterial activity with minimum inhibitory zone of $2 \mathrm{~mm}$ against Pseudomonas aeruginosa and maximum $18 \mathrm{~mm}$ against Klebsiella pneumoniae at $100 \mathrm{mg} / \mathrm{ml}$ concentration. It was further fractionated into four fractions using the different solvent system. Of all the fractions tested, (F2) and) (F3) showed the potent activities. The fraction F2 showed minimum inhibition zone of $9 \mathrm{~mm}$ against Pseudomonas aeruginosa and Proteus vulgaris and the maximum of $14 \mathrm{~mm}$ against Streptococcus pyogenes and F3 showed the minimum inhibition zone of $12 \mathrm{~mm}$ against Klebsiella pneumoniae and $20 \mathrm{~mm}$ against Staphylococcus aureus at $100 \mathrm{mg} / \mathrm{ml}$ concentration. The GC-MS analysis of the whole body tissue extract of Conus achatinus revealed the presence of alkaloid, amino, nitrogen, aldehyde, alcoholic, sulphur, nitrogen and steroid compounds which might be responsible for the antibacterial activity.

Copy Right, IJAR, 2018,. All rights reserved.

\section{Introduction:-}

Oceans offers a large biodiversity of fauna and flora which is estimated to be over 5,00,000 species and more than double that of land. The marine environment is a huge source for of natural products and most of them yet to be discovered. Apart from human medicines, the research on marine natural products in the last three decades has also brought to the discoveries of many chemically and biologically interesting molecules, that have become indispensable tools in biochemical research and played significant roles in the recent advancement of life sciences.

Tincu and Tailor (2004) reported that sessile and slow moving benthic marine organisms are the rich source of bioactive metabolites. These metabolites can be considered as a kind of autogenic protection and are proved to be the timely alternative natural medicine to human beings. Generally, the ocean meets the food requirements of human, a far better profitability is obtained by producing human consumables and the highest profitability is currently expected from bioactive compounds (Je et al., 2005; Jeon and Kim, 2002; Kim et al., 2001). There are more than thousands of bioactive compounds discovered in molluscs. So far, many bioactive compounds like peptides, sterols, terpenes, polypropionates, nitrogeneous compounds, macrolides, prostaglandins, fatty acids derivatives, alkaloids etc., showing specific type of activities have been identified and isolated from molluscs (Mactoob and Ronald., 1997; Balcazer et al., 2006 and Blunt et al., 2006). 
Members of many classes of molluscs possessing bioactive compounds having antitumour, antileukemic, and antibacterial properties have been reported worldwide (Anand et al., 1997; Ilangedone et al., 1999; Rajaganapathy et al., 2000 and Chellaram et al., 2004). Conversely, most medicines are derived from shelled gastropods and bivalves (Kirsten Benkendroff, 2010). The bioactive compounds isolated from these shelled gastropods are considered a role as chemical defense against their predators. Today, the great majority of bacterial infections are easily controlled with natural or synthetic drugs. Antibacterial activity has been previously proved in a wide range of molluscan species (Mitta et al., 2000; Rajaganapathy et al., 2000; Prem Anand and Patterson Edward, 2002; Prema., 2006; Annamalai et al., 2007; Maripandi et al., 2010 and Subavathy, 2012). We are still in need of safer, cheaper and effective drugs. Marine molluscs, are the source of biologically active products is largely unexplored in India. Hence, a broad based screening of marine molluscs is necessary to explore the bioactive compounds.

Due to the above facts, the present study has been undertaken to test the whole body tissue of marine molluscan extract against bacteria and to isolate and characterize the possible antibacterial compound from the test mollusc Conus achatinus.

\section{Material And Methods:-}

Conus achatinus were collected from the Gulf of Mannar in Thoothukudi coastal region during low tides from the sea in its natural habitat. The freshly collected samples were cleaned and washed with fresh seawater to remove all impurities. The shells were broken and the tissues were made into small pieces with aseptic scissors and then dried in hot air oven at $56^{\circ} \mathrm{C}$ for 48 hours and used for further study.

\section{Preparation Of Extracts:-}

Methanol extract of the body tissue was prepared by the technique given by Thilaga (2005) which was slightly modified. Air dried materials were taken and immersed in 100\% A.R. grade methanol for 10 days in room temperature. The extract from the solvent was filtered using Whatman No.1 filter paper. The filtrate was poured into petriplates and evaporated to dryness. The dried substance was used for further studies.

\section{Fractionation:-}

Crude methanol extract was fractionated by silica gel column chromatography with four different solvent systems. Elutions with Hexane Chloroform (F1), Chloroform (F2), Benzene : Methanol (F3) and Distilled water (F4) in the order of their polarity afforded four fractions viz., F1, F2, F3 and F4. A known amount of extracts was taken and their organic solvents were removed by vacuum evaporation. Solids were dissolved in deionized water and concentration series of $1 \mathrm{mg} / \mathrm{ml}, 10 \mathrm{mg} / \mathrm{ml}$ and $100 \mathrm{mg} / \mathrm{ml}$ were prepared and used.

\section{Antibacterial Assay:-}

Antibacterial assay of both crude and column fractionated extracts of Conus achatinus were determined against ten bacterial pathogens through disc diffusion technique. Pseudomonas aeruginosa, Bacillus cereus, Shigella flexneri, Vibrio cholerae, Salmonella typhi, Escherichia coli, Proteus vulgaris, Klebsiella pneumoniae, Streptococcus pyogenes and Staphylococcus aureus which were obtained from the Microbiology Department of Sri Paramakalyani College, Alwarkurichi. These bacterial strains were inoculated in sterile nutrient broths resectively and incubated at $28 \pm 2{ }^{\circ} \mathrm{C}$ for 24 hours. The impregnated discs along with the Control were kept at the centre of the agar plates, seeded with test bacterial cultures. The plates were incubated at $37^{\circ} \mathrm{C}$ for 24 hours and the inhibition zone was measured from the outer side of the discs to the inner side of the inhibition zone. The extract showing broad spectrum antibacterial activity was examined by testing different concentrations viz., $1 \mathrm{mg} / \mathrm{ml}, 10 \mathrm{mg} / \mathrm{ml}$ and $100 \mathrm{mg} / \mathrm{ml}$. Each activity was tested thrice for confirmation of activity. The most potent fraction was characterized to know the functional groups through GC-MS study. GC-MS analysis was carried out on a GC Clarus 500 Perkin Elmer system at Indian Institute of Crop Processing Technology, Tanjore.

\section{Identification Of Compounds:-}

Interpretation on mass spectrum GC-MS was conducted using the data base of National Institute of Standard Technology (NIST) having more than 62,000 patterns. The unknown components with electrons impact fragmentation patterns of the mass spectra of column fractioned test mollusc was matched with the spectrum of the known components stored in NIST ver.21 National Institute of Standard Technology, the mass spectra library and predicted from Dr. Duke's Phytochemical and Ethnobotanical Database. 


\section{Results:-}

In the present study, antibacterial activity of whole body tissue extract of Conus achatinus was tested and presented in figures (1-3) and plates (1-3). The extract showed more pronounced antibacterial activities against some human pathogenic bacterial strains. The crude methanolic extract of Conus achatinus showed the range of activity from $2 \mathrm{~mm}$ to $18 \mathrm{~mm}$. At $100 \mathrm{mg} / \mathrm{ml}$ concentration, the minimum inhibitory zone of $2 \mathrm{~mm}$ against Pseudomonas aeruginosa and maximum of $18 \mathrm{~mm}$ against Klebsiella pneumonia were recorded. Of all the fractions tested, (F2) and (F3) showed the most potent activities. F2 developed minimum inhibitory zone of $9 \mathrm{~mm}$ against Pseudomonas aeruginosa and Proteus vulgaris and maximum $14 \mathrm{~mm}$ against Streptococcus pyogenes. F3 developed inhibition zones which varied from $12 \mathrm{~mm}$ and $20 \mathrm{~mm}$. It showed the minimum inhibitory activity of $12 \mathrm{~mm}$ against Klebsiella pneumoniae and $20 \mathrm{~mm}$ against Staphylococcus aureus at $100 \mathrm{mg} / \mathrm{ml}$ concentration. These promising results revealed, the presence of alkaloid, amino, nitrogen, aldehyde, alcoholic, sulphur, nitrogen and steroid compounds by GC-MS analysis of whole body tissue of Conus achatinus, which might be responsible for the antibacterial activity.

Fig. 1:-Antibacterial activity of crude methanol extract of Conus achatinus

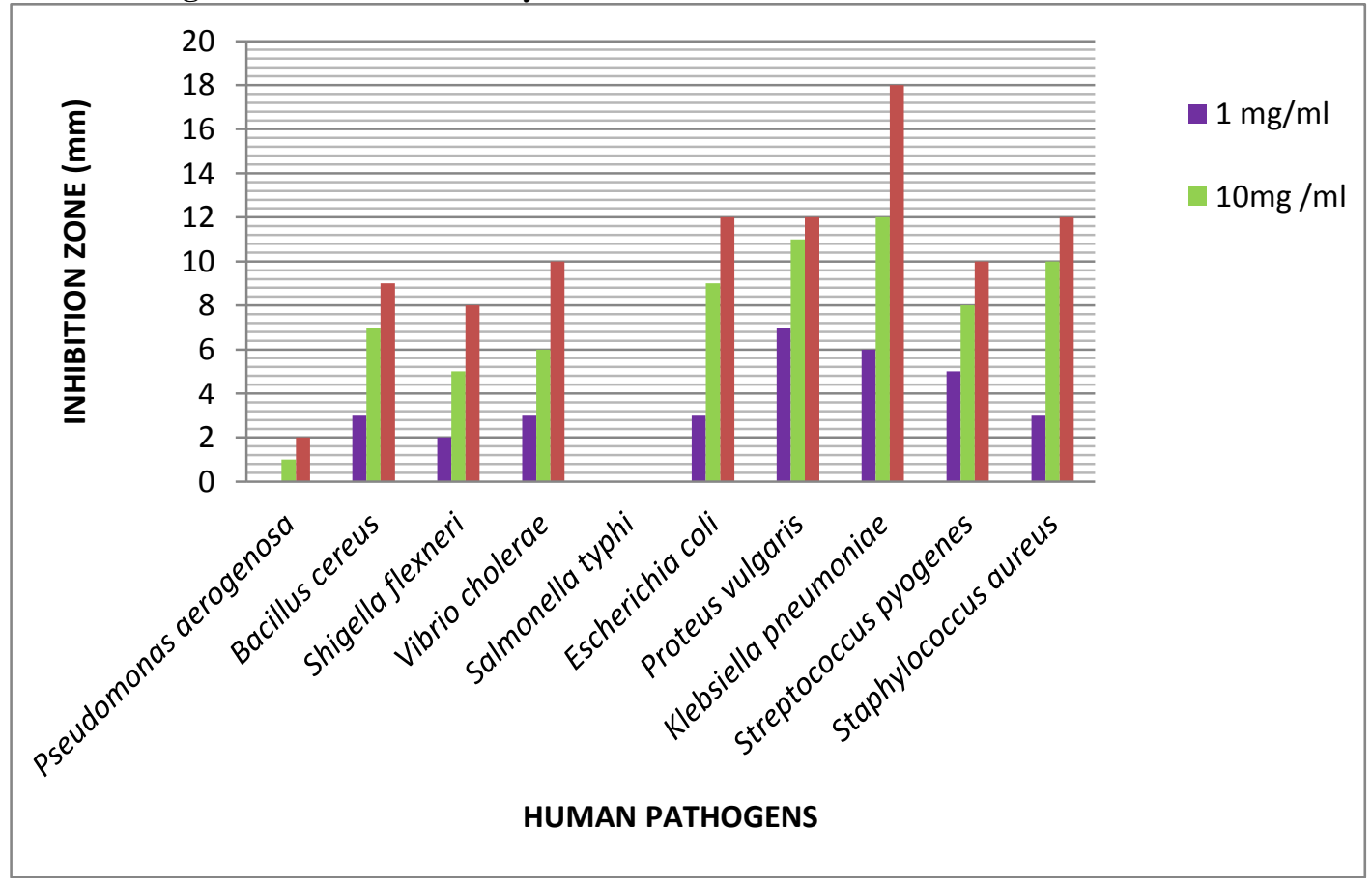


Fig. 2:- Antibacterial activity of F2 fraction (Chloroform) of Conus achatinus

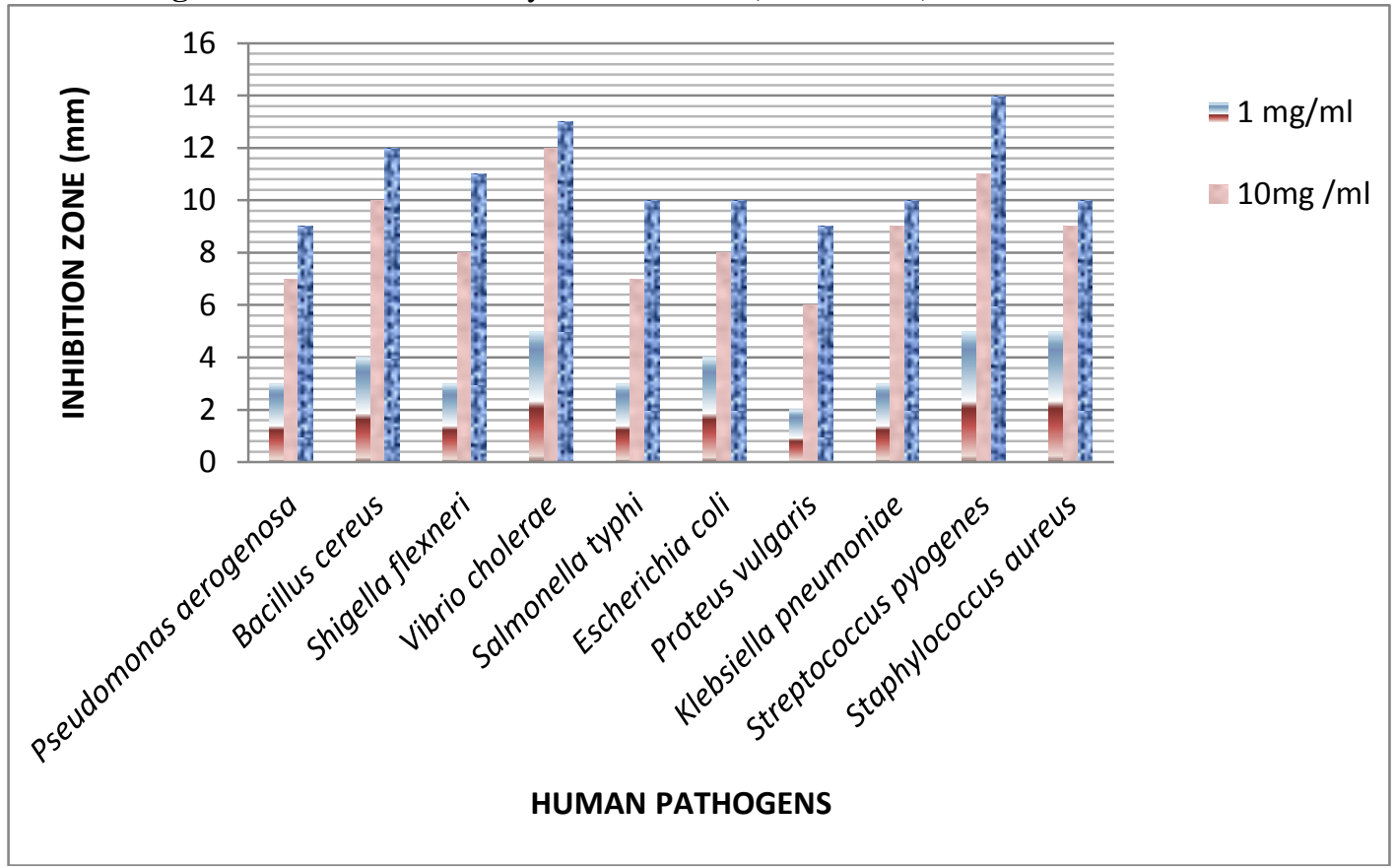

Fig. 3:-Antibacterial activity of F3 fraction (Benzene:Methanol) of Conus achatinus

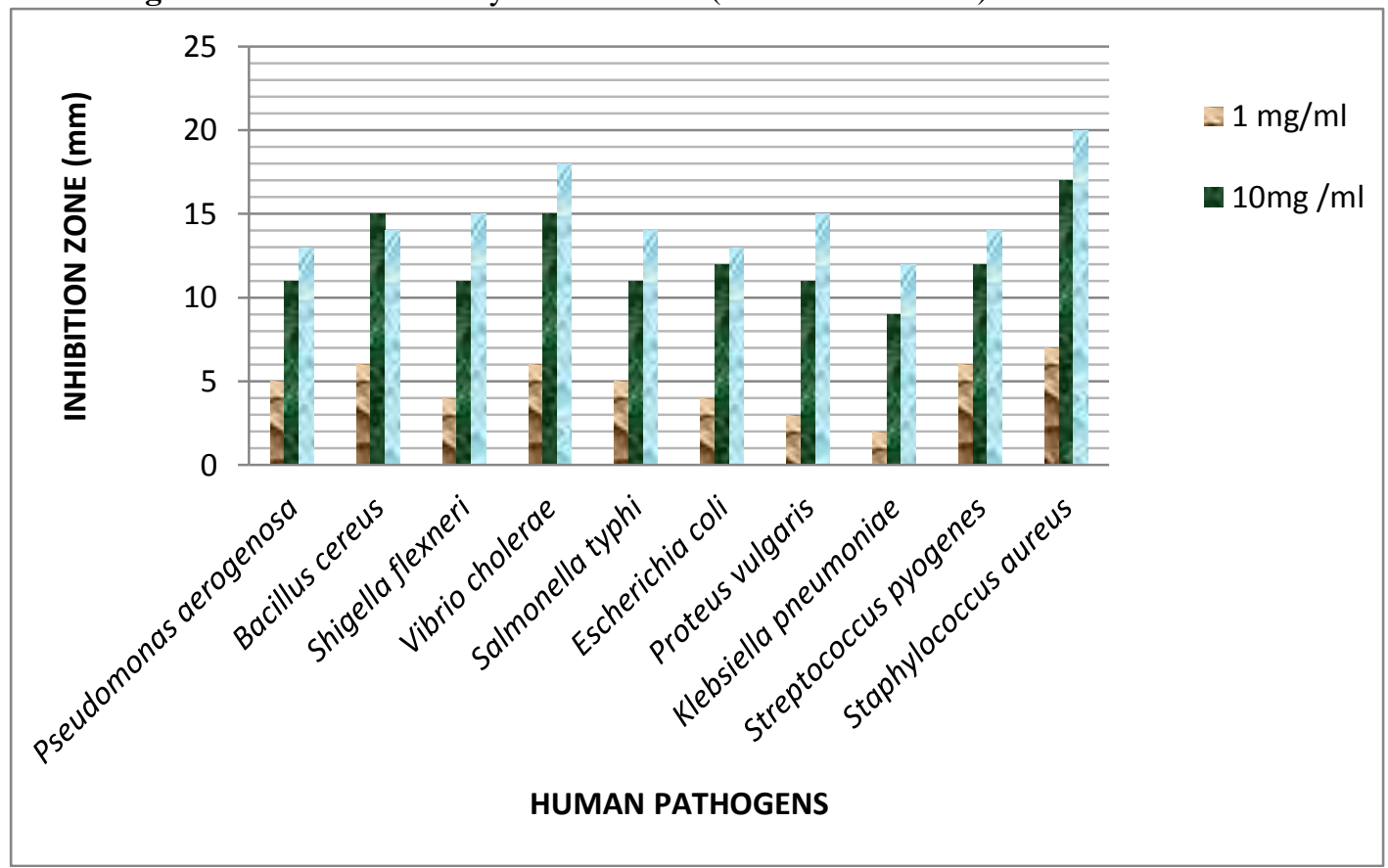


Plate 1:- Antibacterial activity of crude methanol extracts of Conus achatinus

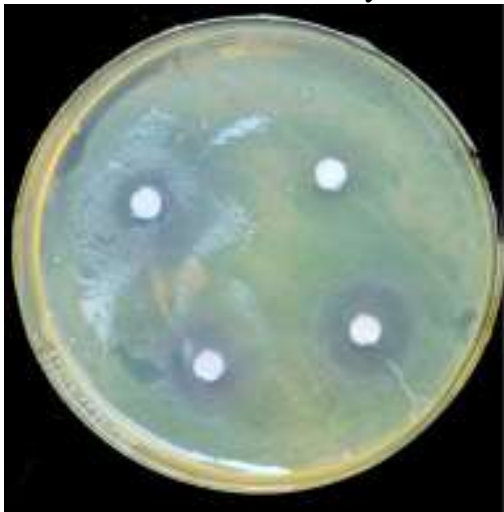

Pseudomonas aeruginosa

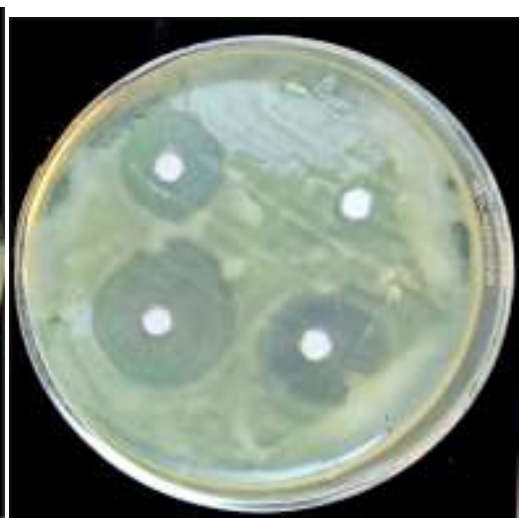

Klebsiella pneumonia

Plate2:- Antibacteria activityofF2 fraction (Chloroform) against.

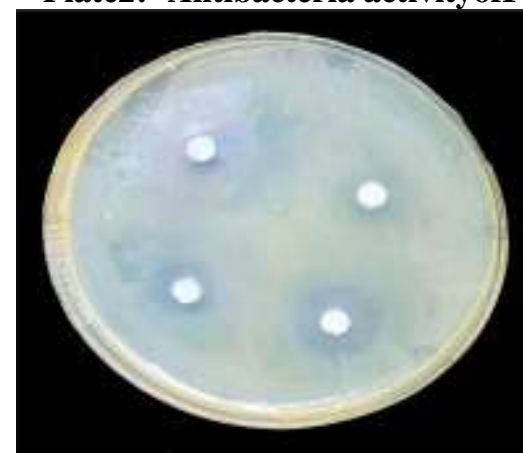

Pseudomonas aeruginosa

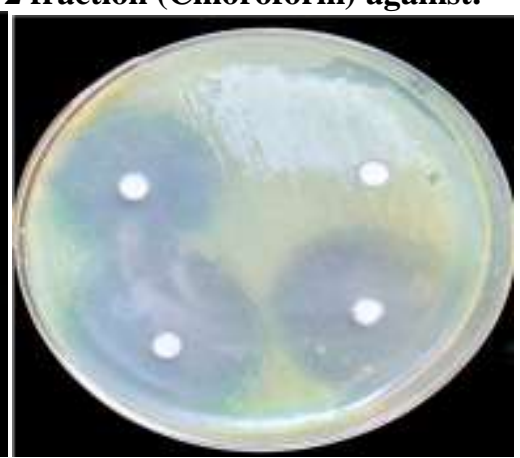

Streptococcus pyogenes

Plate 3:- Antibacterial activity of F3 fraction (Benzene : Methanol) against

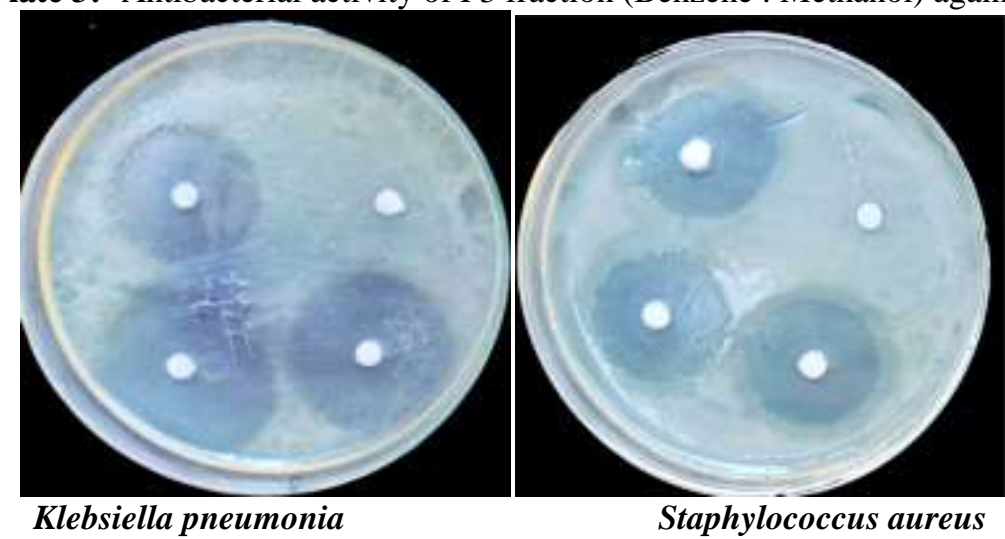

Table 1:- Activity of components identified in Conus achatinus by GC-MS

\begin{tabular}{|c|c|c|c|c|c|}
\hline $\begin{array}{c}\text { S. } \\
\text { No }\end{array}$ & RT & Name of the compound & $\begin{array}{c}\text { Peak } \\
\text { Area } \\
\%\end{array}$ & $\begin{array}{c}\text { Compound } \\
\text { Nature }\end{array}$ & $\begin{array}{c}* * \text { Reported } \\
\text { activity }\end{array}$ \\
\hline 1 & 3.15 & Aziridine, 1-methyl- & 4.75 & Alkaloid & $\begin{array}{c}\text { Antimicrobial } \\
\text { Antiinflammatory }\end{array}$ \\
\hline 2 & 10.37 & 5-Methyl-2-hexanone oxime & 0.33 & Ketone & No activity reported \\
\hline 3 & 10.85 & Cyclohexanol,2-amino-,trans- & 1.73 & Amino & Antimicrobial \\
\hline
\end{tabular}




\begin{tabular}{|c|c|c|c|c|c|}
\hline 4 & 11.41 & Azocine, octahydro- & 0.85 & $\begin{array}{l}\text { Nitrogen } \\
\text { compound }\end{array}$ & Antimicrobial \\
\hline 5 & 12.59 & Butanal, O-methyloxime & 7.29 & $\begin{array}{l}\text { Aldehyde } \\
\text { compound }\end{array}$ & Antimicrobial \\
\hline 6 & 13.2 & L-Homocitrulline & 22.39 & $\begin{array}{l}\text { Nitrogen } \\
\text { compound }\end{array}$ & Antimicrobial \\
\hline 7 & 14.35 & Pentanal, oxime & 0.88 & $\begin{array}{l}\text { Aldehyde } \\
\text { compound }\end{array}$ & Antimicrobial \\
\hline 8 & 14.76 & E-2-Tetradecen-1-ol & 1.77 & $\begin{array}{l}\text { Alcoholic } \\
\text { compound }\end{array}$ & Antimicrobial \\
\hline 9 & 15.47 & Z-10-Pentadecen-1-ol & 1.62 & $\begin{array}{l}\text { Alcoholic } \\
\text { compound }\end{array}$ & Antimicrobial \\
\hline 10 & 15.71 & Lysine & 1.73 & Amino acid & Nutrient \\
\hline 11 & 15.97 & $\begin{array}{l}\text { Trimethylamine, compd. with } \\
\text { borane (11) }\end{array}$ & 0.59 & $\begin{array}{l}\text { Amino } \\
\text { compound }\end{array}$ & Antimicrobial \\
\hline 12 & 16.89 & $\begin{array}{l}\text { 1,1-Cyclopropane dicarbonitrile, } \\
\text { 2,2-dimethyl- }\end{array}$ & 1.18 & $\begin{array}{l}\text { Nitrogen } \\
\text { compound }\end{array}$ & Antimicrobial \\
\hline 13 & 17.46 & $\begin{array}{l}\text { Cyclopentanol, 2-(aminomethyl)-, } \\
\text { cis- }\end{array}$ & 0.41 & $\begin{array}{l}\text { Amino } \\
\text { compound }\end{array}$ & Antimicrobial \\
\hline 14 & 19.8 & Tricyclo[4.2.1.1(2,5)]decan-3-ol & 0.77 & $\begin{array}{l}\text { Alcoholic } \\
\text { compound }\end{array}$ & Antimicrobial \\
\hline 15 & 20.44 & n-Nonanoylmorpholine & 0.63 & $\begin{array}{l}\text { Nitrogen } \\
\text { compound }\end{array}$ & Insect repellent \\
\hline 16 & 21.01 & Thiomorpholine & 0.88 & $\begin{array}{c}\text { Sulphur } \\
\text { compound }\end{array}$ & $\begin{array}{l}\text { Antimicrobial used } \\
\text { in Pharmaceuticals }\end{array}$ \\
\hline 17 & 21.31 & Semioxamazide & & $\begin{array}{c}\text { Amino } \\
\text { compound }\end{array}$ & Antimicrobial \\
\hline 18 & 28.85 & $\begin{array}{l}\text { Cholan-24-oic acid, 3-oxo-, methyl } \\
\text { ester, (5á)- }\end{array}$ & 50.06 & Steroid & $\begin{array}{l}\text { Antimicrobial } \\
\text { Antiinflammatory } \\
\text { Anticancer Antiasthma } \\
\text { Diuretic } \\
\end{array}$ \\
\hline
\end{tabular}

\section{Discussion:-}

In the present study, the whole body tissue extract of the marine gastropod Conus achatinus showed significant antibacterial activity against ten bacterial pathogens. The crude extract showed more pronounced antibacterial activities against some human pathogenic bacterial strains. It could be explained that the bioactive compounds present in the experimental organism might have been developed as chemical defense of animals against their predators (Chellaram and Edward, 2009) living in their specific environment. Anand and Edward (2001) noted that the crude methanol extract of Cypraea errones exhibited promising antibacterial activity. Chellaram et al, (2004) reported that chloroform and acetone extracts of Ptera chinensis showed broad spectral antibacterial activity against eight fish pathogens tested. Similarly Annamalai et al., (2007) reported that Perna viridis showed maximum inhibition against E. coli and Staphylococcus aureus. Anbuselvi (2009) found that acetone column purified fractions of Trochus tentorium showed higher antibacterial activity. Santhi (2011) reported antibacterial activity of the whole body tissue extract of Purpura persica and the results showed wide spectral activity against some pathogens. Antibacterial activity has been previously proved in a wide range of molluscan species (Mitta et al., 2000; Rajaganapathy et al., 2000; Prem Anand and Patterson Edward, 2002; Prema., 2006; Annamalai et al., 2007; Maripandi et al., 2010 and Subavathy, 2012). This could be attributed to the fact that the test extract might contain secondary metabolites which inhibited the growth of bacteria.

Apart from the crude extract, the fractionated extract of Conus achatinus inhibited Klebsiella pneumoniae, Streptococcus pyogenes and Staphylococcus aureus showed promising results in all the pathogens. F2 (Chloroform) fraction showed minimum inhibitory zone of $9 \mathrm{~mm}$ against Pseudomonas aeruginosa and Proteus vulgaris and maximum of $14 \mathrm{~mm}$ against Streptococcus pyogenes. F3 fraction (Benzene:Methanol) of Conus achatinus showed wide spectrum activity by developing maximum inhibition zone of maximum $20 \mathrm{~mm}$ against $S$. aerues and minimum $12 \mathrm{~mm}$ against $K$. pneumoniae. The present finding is a supportive evidence of Rajaganapathy et al, 
(2000) who have reported that the methanol extract from the whole body tissue of Hemifuses pugilinus exhibited activity against $B$. subtilus, E. coli and K. pneumonia. Santhana Ramasamy and Murugan (2003) reported that methanolic extract of Chicoreus virgineus and Chicoreus ramosus showed broad spectrum antibacterial activity of the body tissue extract. Dhinakaran et al., (2011) observed that ethanol and methanol extract of marine gastropod $H$. pugilinus showed maximum antibacterial activity against few pathogens. The above findings corroborate with the observations of the present study.

Antibacterial activity of marine animals and their bioactive products at molecular level have been studied by various authors and the molecules responsible for antibacterial activity have been identified and characterized. The GC-MS analysis of the extract of Conus achatinus revealed eighteen compounds (Table 1). Of the 18 compounds, the following 15 compounds viz., Aziridine, I-methyl, Cyclohexanol, 2-aminotrans, Azocine, octahydro-, Butanal, Omethyloxime, L-Homocitrulline, Pentanal oxime, E-2-Tetradecen-1-ol, Z-10-pentadecen-1-ol, Trimethylamine compound with borane, 1,1-cyclopropane decarbonitrile, 2,2-dimethyl, Cyclopentanol, 2, (aminomethyl)- cis-, Tricyclo [4.2.1.1 (2,5)] decan-3-ol, Thiomorpholine, Semioxamazide and cholan-24-oic acid, 3-oxo-methyl ester (5a)- could be responsible for the antibacterial activity of the present study.

To conclude, the present study clearly showed that among all the fractions, F2 and F3 fractions of the study animal Conus achatinus showed more activity. This may be due to the presence of above mentioned compounds in the body extracts. So, further studies are needed to isolate and characterize these compounds to study their mode of action in pharmacological field.

\section{Acknowledgement:-}

The authors are grateful to UGC for providing financial assistance under which the project [F.No.42/539/2013(SR)]. We also express our sincere thanks to the Principal of St. Mary's College (Autonomous), Thoothukudi for the facilities provided to pursue the research project.

\section{Reference:-}

1. Anand, T.P., J. Rajaganapathy and J.K.P. Edward, 1997. Antibacterial activity of marine mollusc from portonova region. Indian Journal of Mar. Sci. 26: 206-208.

2. Anand, T.P., and J.K. Patterson Edward, 2001. Screening for antibacterial activity in the opercula of gastropods. Phuket Mar. Biol. Cent. Spec. Pub. 25pp : 215-217.

3. Annamalai, N.R., S. Anburaj, S. Jeyalakshmi and R. Thavasi, 2007. Antibacterial activities of green mussel Perna viridis and edible oyster Crassostrea madrasensis. Res. J. Mic., 2 (12): 976-982.

4. Anbuselvi, S., C. Chellaram, S. Jonesh and J.K. Patterson, 2009. Bioactive potential coral associated gastropod, Trochus tentorium of Gulf of Mannar, South Eastern India. J. Med. Sci, 9: 240-244.

5. Balcazer, J.L., I.D. Blas, I. Ruiz-zarzuela, D. Cunmngham, D. Rell and J.J. Muzqulz, 2006. The role of probiotics in aquaculture. Vet. Microbiol. 114, 173-186.

6. Blunt, J.W., B.R. Copp, M.H.G. Munro, P.T. Northcote and M.R. Princep, 2006. Marine natural products. Nat. Prod. Rep. 23: 26-78.

7. Chellaram, C., K. Mary Elizabeth Gnanambal and J.K. Patterson Edward, 2004. Antibacterial activity of the winged oyster Ptera chinensis (Pteroidea, Pteridae) Indian J. Mar. Sci. 33:369-372.

8. Chellaram, C and J.K.P. Edward, 2009. Anti-inflammatory potential of coral reef associated gastropod, Drupa margaritula. Indian J. Sci. Tech.,2; 75-76.

9. Dinakaran. A., V. Sekar, G.V. Sethupathi and J. Priya., 2011. Antipathogenic activity of marine gastropoda (Hemifuses pugilinus) from Pazhayar, Southeast Coast of India. International Journal of Envtl. Sciences. 2(2): 524-530.

10. Ilangedone, M.R., B.J. Barreson and P.J. Scheuer, 1999. Bioactive natural products, Helvetica Chimica Acta, $62 ; 2484-2486$.

11. Je, Y., P.J. Park, W.K. Jung and S.K. Kim., 2005. Isolation of Angiogenesis Converting Enzyme (ACE) inhibitor from fermented oyster source, Crassostrea gigas. Food chemistry, 90: 809-814.

12. Jeon, Y.J and S.K. Kim, 2002. Antitumour activity of chitosan oligosaccharides products in an Ultra filtration membrane reactor system. J. Microbiol. Bioteh. 12: 503-507.

13. Kirston Benkendroff., 2010. Molluscan biological and chemistry diversity, secondary metabolites and medicinal resources produced by marine molluscs. Biological Reviews, 85 (4), 757-775. 
14. Kim, S.K.,Y.T. Kim, H.G. Byun, K.S. Nam, D.S. Joo and F. Shanhidi, 2001. Isolation and characterization of antioxidative peptides from gelatine hydeolysate of Allaska Pollack skin. J. Agri. Food Chem. 49:1984-1989.

15. Maktoob, A and H.T. Ronald, 1997. Handbook of natural products from marine invertebrates. Phylum mollusca part I. Hardwood academic publishers, pp. 1-288

16. Maripandi, A., L. Prakash Ali and A. Salamah, 2010. HPTLC separation of antibacterial compounds from Perna viridis and Portunus sanguindentus and pits activity tested against common bacterial pathogens. Advanced biotech. Vol. 9.

17. Mitta, G., F. Hubert, E.A. Dyrinda, P. Boudry and P. Roch, 2000. Mytilin B and antimicrobial peptides of marine mussels; gene structure and expression analysis. Dev. Com. Immunol, 24,pp.381-393.

18. Prema, D., N.K. Sail and P.S. Sivaprasad, 2006. Antibacterial activity of Crassostrea madrasensis and villorita, Perna viridis (Mollusca pelicipoda) of India. Cent. Fish. Res. Inst. Spl. Publication. 88:67pp.

19. Prem Anand, T. and J.K. Patterson Edward, 2002. Antibacterial activity in the tissue extracts of Five species of Cowries cyprae sp. (Mollusca: Gastropod) and ascidian Didemnin psammathodes (Tunicate: Didemnidae). Indian. J. Mar. Sci. 31:239-242.

20. Rajaganapathy, J.,K. Kathiresan and T.P. Singh, 2000. Purification of Anti-HIV protein from purple fluid of the sea hare Bursatella leachii Blainville. J. Mar. Biotechnol., 4: 447-453.

21. Santhanaramasamy, $\mathbf{M}$ and A. Murugan, 2003. Correlation between bacterial epibiosis and fouling detergent activity of Distaplia nathensis and Polydinum consetellatum. SDMRI Research Publications; 3, 165-167.

22. Santhi, V., V. Sivakumar, A. Thangathirupathi and R.D. Thilaga, 2011. Analgesic, antipyretic and antiinflammatory activities of chloroform extract of prosobranch mollusc Purpura persica. Int. J. Pharmacol. Bio. Sci. 5 (2): 915.

23. Subavathy, P., 2012. Exploration of digestive physiology, biochemistry and bioprospecting potential of a gastropod Fusinus nicobaricus (Roding, 1798) from Gulf of Mannar, M.Phil Thesis. Manonmaniam Sundaranar University, India.

24. Thilaga, R.D., 2005. Studies on some Ecological aspects of Babylonia spirata (Linn) along the Tuticorin Coast Ph.D Thesis. M.S. University, Tirunelveli, pp-1-244.

25. Tincu J.A and Tailor, 2004. Antimicrobial peptides from marine invertebrates. Antimicrob. Agents Chemother. 48: 3645-3654. 